- Despite commitments to socially responsible investing on the part of many institutional investors, SRI funds have not experienced corresponding growth in assets under management and have struggled to generate business revenue.

\section{Strategically Reasonable Indifference?}

\section{Asset owners challenged on SRI commitment}

BY MAHA KHAN PHILLIPS

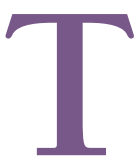
he announcement in January 2012 caused consternation in the world of responsible investing Aviva Investors in the U.K. was to cut 160 jobs. Among those affected would be its socially responsible investments (SRI) division, an area where Aviva is well regarded.

"This is a big question for the asset management industry," said chief executive Alain Dromer. "We at Aviva have had a seriously important team in this field and it's fair to say that investors want to maintain principles of sustainability in our investments. But we don't see the business coming. These are themes that do not particularly generate any revenues. Funds under management in our SRI funds have been stagnant."

There's the rub. On paper, institutional investors are fully committed to sustainability, which often falls under the bracket of environmental, social, and corporate governance (ESG) initiatives. For example, in the U.K., 40 pension funds and asset owners have signed up for the U.K. Stewardship Code, which aims to enhance the quality of engagement between institutional investors and companies. But according to Aviva, pension funds have not changed their behaviour after signing up to the code. Industry participants argue that in practice (in a low-return environment) not all investors, whether retail or institutional, want to deal with issues of responsible investing.

A December 2011 report titled "Corporate Pension Funds \& Sustainable Investment Study" by the European Sustainable Investment Forum (Eurosif) revealed that, although two-thirds of corporate pension funds believe that having an SRI policy is a part of investors' fiduciary duty, only about a quarter of respondents planned on implementing one over the next 12 months.

"At the moment, there is limited appetite for many types of funds [not just socially responsible ones]. Clients are looking at asset allocation, at how they should protect their assets for what people think will be challenging markets," says Will Oulton, head of responsible investment for Europe at global financial consultant Mercer. He notes that asset owners, not fund managers, have to push through the agenda. "What is lagging," he says, "is the commitment and signals from asset owners, the pension funds and insurance schemes. They should push this along faster within their
- Perceived underperformance may discourage investors from increasing allocations to SRI themes, but geographic variance is also a factor.

- Some research suggests that more efficient diversification can enable investors to outperform using SRI screens.

- The composition of indices and how investors use them can also have a significant impact on performance.

own investment approaches."

Consistently strong performance would help. The Dow Jones Global Titans 50 Index returned -1.49 percent in 2011 while its counterpart, the Dow Jones Sustainability World 80 Price Index, returned -9.66 percent. In Europe, the Dow Jones Europe Titans 80 Index returned -12.83 percent while the Dow Jones Sustainability Europe 40 Index returned -14.80 percent. In the U.S., the DJIA returned 5.53 percent while the Dow Jones Sustainability US 40 Price Index returned -1.90 percent.

"What is lagging is the commitment and signals from asset owners, the pension funds and insurance schemes. They should push this along faster within their own investment approaches."

Given such numbers, it is easy to see why investors might not buy into sustainability right now. "The fact of the matter is that when you put on your suit and look your best, you say you are a long-term investor. But when you get into your cubby hole and look at your portfolio, you are really looking at short-term performance," says John Prestbo, executive director for Dow Jones Indexes. "Institutional investors will say they are in it for the long term. Well, wait till the market goes down and then see what they do."

Prestbo argues that over the long term, sustainable investments do not underperform, because companies develop better practices. "The message is that it doesn't cost you money over the long term to invest in companies practicing sustainability," he says.

\section{Performance}

Of course, the SRI category encompasses a great variety of products and approaches. Last year, Cedrus, a French investment consultant, found that investors in SRI thematic funds (which base investment decisions on a specific 
theme, whether climate change or clean water) were taking their money out while investors in other SRI funds kept their allocations at the same level. Cedrus identified 310 sustainability-focused equity funds globally. Of these, 165 were ESG funds, which had $€ 22$ billion in assets under management at the end of September 2011. The remaining 145 funds were thematic funds, which had $€ 15$ billion in assets under management globally.

The importance of ethical issues varies considerably by country. More than 75 percent of German, Dutch, Danish, and Swedish investors say they exclude companies from their portfolios based on negative screening, according to Paris-based SRI research center Novethic. Among U.K. and French respondents, the rate drops below 40 percent.

Sustainability is also about perception. In 2008, France's EDHEC-Risk Institute published a study looking at SRI funds distributed in France over a six-year period ending December 2007. The vast majority of funds produced negative or non-significant alpha. The study was extended again in September 2010 to take into account the financial crisis and whether it made a difference to the performance of sustainable funds. Again, funds produced negative alpha. "We also found that SRI did not protect you. In fact, you were more exposed to extreme risk during the financial crisis," explains Eric Shirbini, business development director at EDHEC-Risk Indices and Benchmarks.

EDHEC researchers then decided to evaluate two prevailing views about responsible investing and look for some middle ground. The first view is that negative screening (in which indices exclude companies that are not sustainable) leads to a smaller investment universe, which in turn causes poor diversification, efficiency losses, and industry and style biases, resulting in underperformance. The other view is that none of this matters. SRI proponents argue that the social benefits have an impact on long-term performance, even though they are hard to quantify and define.

"The question is, How do you reconcile these different points of view? We think they can be reconciled by separating stock selection and stock weighting," explains Shirbini. EDHEC researchers argued that investors can achieve outperformance with indices if they use efficient weights. Most SRI investment processes focus on stock selection (based on individual qualities of companies according to ESG criteria) and stock weighting, with most SRI funds using either a cap-weighting scheme or an ESG score or a combination of the two.

EDHEC's response (in collaboration with French civil servants pension fund ERAFP, which runs a 100 percent SRI strategy) was to produce what it calls an efficient index, which aims to improve diversification through portfolio-construction techniques. "We optimised the portfolio, and we created efficient weights," Shirbini explains. "Then we ran performance and found that you can outperform with an SRI screen, provided you use better diversification in your portfolio. We found that you are able to outperform by roughly 1.5 percent a year."

The findings raise the question of how investors use indices. "Weighting differences do make a difference in performance, absolutely," says Prestbo. "If we were to equally weight our world index, it would have a different performance than if we weighted it by market cap, which is what it is. And if we wanted to show better performance, we'd equally weight the index, thus reducing the impact of European companies which underperformed in 2011. But our job is to measure the market."

\section{MAKING SRI A PRIORITY}

U.S. teachers' pension scheme TIAA-CREF, with more than US $\$ 440$ billion in assets under management, has been involved in impact investing and SRI since 2006. The fund uses ESG factors to manage US\$11 billion in assets. "Our commitment exists because we do see evidence for growth and increasing demand going forward," says Amy O’Brien, director of social and community investing. While the majority of its business is still on the pension side, TIAA-CREF has won mandates from other asset owners because of its impactinvesting approach. "We seek a favorable long-term rate of return that reflects the financial performance of the market as a whole-but while giving special consideration to ESG criteria," says O’Brien. "We prioritize both, as do our clients. The discipline is no longer considered a zero-sum game." TIAA-CREF has also committed to impact investing, with assets in the area of approximately US\$800 million. "We launched a commitment to microfinance, and that's an active commitment. It's a global program. In the U.S., we are looking at what can be done to provide capital to underserved communities and populations. We also have a commitment to sustainable real estate," says 0’Brien. [For more on microfinance, see feature article on p. 64.]

In Europe, APG, the $€ 280$ billion asset manager set up by pension funds in the Netherlands, including the ABP, the country's largest pension fund, integrates a responsibleinvestment policy across all strategies and asset classes. "We have a very clear mandate that the integration of ESG factors should contribute to risk-adjusted returns and that our engagement work in particular helps demonstrate social responsibility. And then the third aspect is to contribute to the integrity of financial markets," explains Claudia Kruse, head of governance and sustainability at APG. Having a holistic view across the portfolio means that performance and sustainability go side by side, as does risk. "Every investment above a certain size has to go through an internal approval process. We look at risk, particularly downside risk, and a detailed ESG assessment is a requirement before an investment is considered for approval," Kruse explains. On the environmental side, the firm is looking increasingly at energy-efficiency opportunities for companies, she explains. 


\section{Different Strokes}

In 2010, Dow Jones came under fire when it was revealed that Halliburton, the oil-field services company, was added to Dow Jones' sustainability index, replacing BP, which was stripped from the index after the blowout of its deep-water well in the Gulf of Mexico. The decision by Dow Jones to include Halliburton caused some confusion because Halliburton was implicated in the same oil-spill disaster.

The case points out the limitations of SRI indices. "When people think of sustainability, they are not thinking of Halliburton," says Usman Hayat, CFA, director of Islamic finance and ESG Investing at CFA Institute. "But most indices don't have room for judgment; they have to follow a certain set of rules. Whether it is Halliburton or someone else, you just have to accept it. The question becomes, Are we losing the spirit [of sustainability] when we just focus on the rules? That is not what people are interested in."

“Then we ran performance and found that you can outperform with an SRI screen, provided you use better diversification in your portfolio."

Hayat provides another example of a perplexing stock. "McDonalds has been reducing its use of plastic and increasing efficiencies in the way it consumes energy, and it's been reducing waste," says Hayat. "But for some people, including it in an index is counterintuitive because it is junk food. Others aren't concerned about whether it is healthy or unhealthy; they are just investors who want to see the company do a better job of reducing costs. So people have a different way of approaching these things and labels can mean different things to different people."

\section{Activism}

Investors who have concerns about performance can go down the activist route instead. This does not mean "Occupy" movements around the world but engagement with companies through fund managers who look to add alpha by transforming company practices. Governance for Owners (GO) is a specialist fund manager that seeks to add long-term value to publicly quoted equities by means of shareholder engagement and good stewardship techniques. The firm's $€ 1$ billion Europe Focus Fund, as measured against the MSCI Europe SMID index, has beaten its benchmark by 3.3 percent per annum since inception until the end of February 2012 and by 4.9 percent per annum over the past three years, according to Robert Machell, CFA, partner at GO. "Interestingly, part of our client base comes out of the U.S., which has got the idea before some of their European peers," says Machell. "Activism ranges from aggression all the way to the other side of the spectrum. Our strategy is to work with management to create change. You get the results quicker, and there is a bigger upside as well. We believe that every company we invest in is undervalued, that there is something that is holding back the share price."

\section{Climate Change}

One area of responsible investing is receiving a lot of attention. In February, Al Gore suggested that asset prices were overvalued because the market was ignoring the impact of climate change. "Prices are based on the assumption that it is ok that there's 90 million tonnes of carbon being pumped into the earth's atmosphere every day," said the former U.S. vice president, who co-founded Generation Investment Management in 2003 (with David Blood, the former chief executive officer of Goldman Sachs).

A collaborative study on climate change by Mercer in 2011 and a follow-up report in January 2012 revealed that of 12 investors representing US $\$ 2$ trillion in assets under management, more than half have decided to include climate-change considerations in future risk management and strategic asset allocation processes. And 80 percent have increased or will increase their engagement on climate change with companies and policy makers.

But there is frustration among those pushing for responsible capitalism, such as the Climate Bonds Initiative, an international network that promotes the development and use of climate bonds, with the aim of providing large-scale issuance of long-term debt to overcome medium-term barriers to achieving economies of scale in lowcarbon industry sectors. "From our point of view," says CBI co-founder Sean Kidney, "we are always underresourced. The resource lack on our side is a response to a lack of resource on the buy side, where institutional investors in particular don't have an ability to screen on anything other than credit grounds."

When markets improve, however, investors are bound to look at the issues in more detail. The challenges of climate change and sustainability are not going to go away any time soon.

Maha Kan Phillips is a financial journalist based in London and author of the novel Beautiful from This Angle.

\section{RECOMMENDED RESOURCES}

"Portfolio Optimization in a Multidimensional Structural-Default Model with a Focus on Private Equity" Summarized in CFA Digest (www.cfapubs.org)

“Investing in Private Equity" CFA Institute Webcast (www.cfawebcasts.org)

"How Do Private Equity Investors Create Value? A Summary of Findings from Ernst \& Young's Extensive Research in North America over the Past Four Years" Summarized in CFA Digest (www.cfapubs.org) 